\title{
What Does It Take to Become a Partner at a Big 4 Accounting Firm? Insights From Singapore's Experience
}

\author{
Gary Pan (Corresponding author) \\ School of Accountancy, Singapore Management University \\ 60 Stamford Road, Singapore 178900 \\ E-mail: garypan@smu.edu.sg
}

Poh-Sun Seow

School of Accountancy, Singapore Management University

60 Stamford Road, Singapore 178900

Yang Hoong Pang

School of Accountancy, Singapore Management University

60 Stamford Road, Singapore 178900

Kwong Sin Leong

School of Accountancy, Singapore Management University

60 Stamford Road, Singapore 178900

This research was supported by the Singapore Ministry of Education (MOE) Academic Research Fund (AcRF) Tier 1 grant (C206/MSS15A001).

Received: May 13, 2018

doi:10.5296/ijafr.v8i2.13133
Accepted: May 25, 2018

Published: June 11, 2018

URL: https://doi.org/10.5296/ijafr.v8i2.13133 


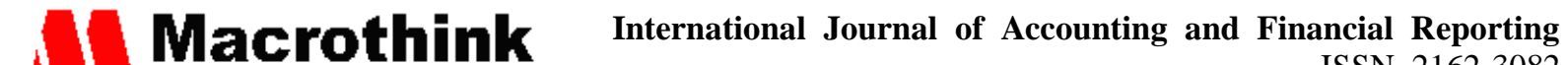 ISSN 2162-3082 2018, Vol. 8, No. 2}

\section{Abstract}

Due to the shift in partner's identity, there have been growing interests in understanding characteristics, skills and behaviours of accounting partners. Given that Big 4 Accounting firms are supposedly international accounting firms that are organized in similar structures, an interesting question of whether the same partner qualities can be applied in the Big 4 accounting firms for a non-western context such as Asia. As far as we know, no such study has been conducted in an Asian context. We argue this could be of great interest to the Big 4 Accounting firms as Asia is one of their fastest growing regions and it is essential they have partners who are equipped with the right attributes to ride the waves of rapid growth. Accordingly, our research aims to identify the essential attributes of a partner in the Big 4 accounting firms in Singapore.

Our data collection involved interviewing 24 partners and 'partners-to-be' from the Big 4 Accounting firms in Singapore. From the data, we identified a number of attributes of a partner. Essential attributes include technical expertise, strong client relationship, solid leadership skill, team management skill, a strong sense of integrity and ethics, and good business sense. There are a few 'good to have' attributes that include overseas exposure, being IT savvy and having ' $\mathrm{X}$ ' factor. Our study also highlighted that nurturing partner attributes may involve a development process. Mechanisms within the partner development process include having senior partners to be mentor, imitate a role model, sense-making through leadership and wide exposure to clients.

Keywords: Attributes, Partner, Big 4 accounting firm, Singapore

\section{Introduction}

Reaching partnership at a Big 4 accounting firm (Note 1) is regarded the pinnacle of achievement for any accountant. Ask any early-career employee in a Big 4 accounting firm whether he or she wants to make partner one day. Many of them will say yes, unequivocally. Making partner at a Big 4 accounting firm is appealing to many because of the perceived status, undoubted financial rewards, and an endorsement of one's skills and experience in the accounting profession. Also as a partner, one becomes a business owner and can influence how the accounting firm is run.

Research has shown that partners have evolved into organizational entrepreneurs (Covaleski, Dirsmith, Heian, \& Samuel, 1998; Greenwood \& Suddaby, 2006; Sikka, 2008) who are perceived as aggressive pursuers of new business opportunities (Gendron \& Spira, 2010; Malsch \& Gendron, 2013), running their micro-businesses within the larger firm (Kornberger, Justesen, \& Mouritsen, 2011) and are expected to bring in revenue. This has shifted the nature of the work from accounting profession-centric to client-centric (Barrett et al., 2005; Robson, Humphrey, Khalifa, \& Jones, 2007), hence creating a "client as king ethos" (Carter \& Spence, 2014, p. 950).

Due to the shift in partner's identity, there have been growing interests in understanding characteristics, skills and behaviours of accounting managers (Kornberger, Justesen \& Mouritsen, 2011) and partners (Carter and Spence, 2014; Spence, Dambrin, Carter, Husillos, 


\section{Macrothink}

International Journal of Accounting and Financial Reporting ISSN 2162-3082

$\&$ Archel, 2014). In one of the studies on partner attributes, Carter and Spence (2014) examined accounting professionals in Canada and the UK, and determined what it means to be a partner in these two countries. Carter, Spence and Dambrin (2014) extended the study by interviewing partners in the Big 4 accounting firms in France and compared the partner qualities among Canada, UK and France. Their study found that there are both similarities and differences in partner attributes across these countries. For example, an interesting difference between France and the other two countries is the education background of individuals. In France, education background is a determinant of future success in the Big 4 accounting firms. Having graduated from a top school marks out a Big 4 employee as special and puts him or her onto a different career trajectory from others who had attended more routine universities. Qualification becomes even more important at the partner level. This fact is a stark contrast to the British and Canadian experiences where the treatment is much more homogeneous.

Given that the Big 4 Accounting firms are supposedly international accounting firms that are organized in similar structures and that, these three countries generally share rather similar cultures, it is indeed surprising to find out there are differences in partner attributes. This raises an even more interesting question of whether the same partner qualities can be applied in the Big 4 accounting firms for a non-western context such as Asia. As far as we know, no such study has been conducted in an Asian context, such as Singapore. We argue this could be of great interest to the Big 4 Accounting firms as Asia is one of their fastest growing regions and it is essential they have partners who are equipped with the right attributes to ride the waves of rapid growth.

With this motivation in mind, we set out to examine what attributes are important to make partner in the Big 4 accounting firms in Singapore.

\section{Literature Review}

With globalization, the accounting profession has undergone significant changes over the years (Cooper \& Robson, 2006; Spence \& Carter, 2014; Suddaby, Gendron, \& Lam, 2009). Numerous studies have indicated inexorable embrace of commercialism in accounting practice (Malsch \& Gendron, 2013; Suddaby et al., 2007; Malsch \& Gendron, 2013; Sikka, 2009; Spence \& Carter, 2014). Partners' identity has shifted from an accountant to an entrepreneur (Greenwood \& Suddaby, 2006). Given the commercialization of the Big 4 accounting firms, partners are expected to act entrepreneurially and in pursuit of new business opportunities.

The changing accounting profession landscape requires skillsets, such as having good client management, building relationships and generating growth for the firm (Carter \& Spence, 2014). Carter \& Spence (2014) state that partners of the past exhibited more technical competencies while today's partners need to exhibit more people-skills in order to generate more revenue. McCracken et al. (2008) also suggest that it is important for audit partner to maintain relationship with customers. 


\section{Mll Macrothink}

International Journal of Accounting and Financial Reporting

ISSN 2162-3082

2018, Vol. 8, No. 2

The focus on revenue generation and client service require partners to be more dynamic, outgoing, multifarious and adaptive to business environment (Carter and Spence, 2014). This highlights the importance of partners having the 'right' attributes to manage fast changing and disruptive business environment. For example, besides technical knowledge, Grey (1998) observes that partners require social and interpersonal skills which are essential in customer engagement and relationship building. This also suggests creativity, critical thinking and clarity of articulation are perceived as highly as technical skills (Smith and Briggs, 1999). Communication skill is important in holding appropriate and significant conversations with customers so as to generate and maintain rapport with them.

Overall, our review of the accounting literature has suggested that there is strong interest in studying the attributes of a partner in big 4 accounting firms. Prior research has focused on understanding partner attributes in Western context. So far there is no study that we are aware of that examines the same phenomenon in an Asian context. As a consequence, our primary aim of the research is to plug this knowledge gap by uncovering what individual attributes are important in making partner at the Big 4 accounting firms in an Asian context, such as Singapore.

\section{Research Method}

We adopted the qualitative interview approach for this study. The qualitative approach is particularly appropriate for our exploratory study since it allows us to better capture the dynamics of the phenomenon (Yin, 2003). Our strategy was to study the process and of making partners at the Big 4 accounting firms. We successfully obtained access to the Big 4 Accounting firms and carried out extensive interviews with several interviewees. The data collection process drew on participants' perceptions of essential attributes of partners in the Big 4 accounting firms in Singapore. These transcripts formed the main repository of data for subsequent analysis. Overall our goal was to expand and generalize theories and not statistical generalization (Yin, 2003).

We set out to address our research question by interviewing partners and 'partners-to-be' in the Big 4 accounting firms in Singapore between February and June 2016. Semi-structured interviews and informal discussions were conducted with our interviewees. These interviews were tape-recorded with interviewees' permission and transcribed immediately afterwards. Each interview lasted an average of one to one and a half hours. Interview questions were open-ended and exploratory to allow opinions to be expressed. They allowed the researchers to interpret the interviewees' opinions, as well as their beliefs. We were particularly interested in the process of making partner, and more importantly, the attributes of the individuals who ultimately become partners. Altogether, we interviewed 20 partners and 4 'partners-to-be' from the Big 4 firms. We interviewed 6 individuals from each of the Big 4 accounting firms.

The interview questions include career background of interviewees, hiring criteria for fresh graduates, the variation in attributes across various ranks in the Big 4, the key attributes of Big 4 employees who can make partners, the skill sets required across various fields such as 


\section{Macrothink}

International Journal of Accounting and Financial Reporting

ISSN 2162-3082

Tax, Audit and Consulting, and the changes in partner attributes over time. Please refer to Appendix A for a list of sample interview questions.

In terms of data analysis, we recursively iterated between the interview data and the accounting literature. The iteration helped to shape our findings. To establish the reliability of coding of the data, each coder was asked to quote a particular segment of the relevant texts. Coding was conducted independently and without consultation and guidance. We examined the portions of the coding where both coders agreed and measured the inter-coder reliability. Our coefficient score suggested substantial agreement between the two coders, and the result demonstrated that the categories were clearly defined and could be located in the text with little ambiguity. Our analysis includes reading all transcripts, highlighting descriptions and developing a list of relevant themes.

\section{Results}

\section{Criteria for Big 4 Recruits}

In general, most interviewees regard academic strength as important in order to get shortlisted for an interview. Most interviewees also think that technical skills in accounting or an accounting related degree are important. Inquisitiveness is another trait that is prized by many partners, as willingness to learn opens doors for innovation. The accounting standards often change, which requires a hunger for learning in order to remain relevant to the accounting profession. Big 4 firms are increasingly looking for graduates who are able to think out of the box and challenge the norms.

"Today, since IASB has full time staff, it (accounting standard) probably changed about 5 times over...So the technical knowledge is going to be the ability to learn." Interviewee.

Soft skills such as communication and networking skills are also valued by the partners. Active involvement in extra-curricular activities is another important factor as it demonstrates the ability to work in teams, according to many partners.

"Social skills are important because our business is all about dealing with people. Whether you are an auditor or tax person, you need to know how to make other people comfortable, you need to get information from clients, you need to interact with them and give them good advice." - Interviewee.

\section{Path to Making Partner}

Typically an individual spends his or her first 4 years in the Big 4 firm as an Associate and subsequently as a Senior. At this stage, client interaction is minimum. As such, the consensus is that individuals must be trained to be technically sound above all else.

A few Partners added that communicating ideas to colleagues and superiors, hence developing an ability to supervise and lead teams in overseeing specific engagements, is also important for Associates and Seniors. 


\section{Macrothink}

International Journal of Accounting and Financial Reporting

ISSN 2162-3082

2018, Vol. 8, No. 2

"I think the basic technical skills, whether you get it through an accounting degree or you get it through the Chartered Accountant pathway, is the core, the foundational skills. And actually, the success beyond that, in my mind, actually goes into the other areas like soft skills, like management skills, like social skills, and so forth." Interviewee.

Advancement to a managerial position in a Big 4 firm entails an aptitude in relationship building with both internal (project teams, other managers and partners) and external stakeholders (clients), and the ability to switch one's attention between several ongoing projects. At this stage, an individual's technical competency is assumed to be of the highest standard in comparison to soft skills.

"There is a school of thought; you are the most technically competent when you are an experienced senior. And as you continue beyond, your technical knowledge starts to drift off as you become more focused on managing clients, managing business, managing relationships, and managing people." - Interviewee.

According to the interviewees, a unifying practice among all Big 4 firms across service lines is that everyone is assigned a formal mentor upon entry. All interviewees see mentors as individuals who play a crucial role in instilling a sense of belonging and confidence in the fast paced Big 4 corporate culture, as well as in bringing out the full potential of an individual through providing a safe, consultative environment for learning and improvement.

"A good mentor will be able to coach you along the way, to see how you can do better, and motivate you to stay in the profession." - Interviewee.

A widely held belief that it is essential to possess an accounting degree in order to be in a top position in the Big 4 corporate hierarchy has been proven fallacious. Expectantly, the majority of the Partners possess an accounting degree. However, we were told some were able to make partner with degrees unrelated to accounting. Regardless, a common trait binding all the aforementioned interviewees is their pursuit of an accounting professional qualification. These results are indicative of the persisting regard for certified proof of technical competency for a commanding position in Big 4 firms, though not specific to a university degree per se.

By and large, the interviewees have been part of a Big 4 firm in the same or related disciplines ever since graduating from universities, attaining the position of Partner after 12 to 15 years of employment. It appears to be common for Partners to have been assigned to branches of the Big 4 in different regions and also experienced multiple intra service line transfers to broaden their perspectives across industries, though inter service line transfers are rare despite them being readily offered by the Big 4 firms.

\section{Essential Attributes of a Big 4 Partner}

There are many criteria that the Big 4 firms use to assess a potential partner. Technical expertise is seen as a given requirement. Besides technical excellence, the candidate must have strong client relationship, solid leadership skill, a strong sense of integrity and ethics, 
and good business sense - it is the partners' job to manage costs and ensure that the practice remains profitable.

Having a strong "business sense" is highly important for making a new partner. Essentially firms look at the billing benchmarks that a partner is expected to achieve and evaluate whether the potential partner is able to deliver a certain level of revenue and profitability. The interviewees commented that candidates with a reputation for integrity and for being an excellent accounting professional who can build relationships, are usually those who can bring business to the firm.

"You cannot be a technocrat and be expected to be made a partner. Because a partner is all about growing the business." - Interviewee.

"It is the personal brand and this is something that all partners need because in order for us to succeed in our business, it is all about relationship and how you build your own personal brand with the people that you work with, how you build your personal brand in the market that you operate in. So you need to be trusted, you need to be known in the market place as someone who can provide solutions to your clients, someone that they can turn to." - Interviewee.

The partners must also have the trust and confidence of their new partners. Part of the stewardship involves identifying and developing successors. Big 4 firms look for partners who can train, mentor and develop the type of accounting professionals that clients and others will trust and want to work with.

One of the most important characteristics highlighted by the interviewees is entrepreneurial acumen, i.e., the ability to feed the bottom line through strengthening existing ones and creating new client relationships.

"In the past when you are very technical, you can make a partner. But in the present environment, I think we have changed. Technical expertise is a given. We also have to be more business-minded." - Interviewee.

Complementing the importance of client relationships are a host of vital soft skills, with client management skill being the most commonly mentioned, followed by communication skill, something crucial in articulating ideas to clients.

Several interviewees highlighted the importance of leadership and team management skill in motivating and bringing out the potential in employees.

A few Partners shared the importance of having the "X Factor" that creates value for the firm, where an individual must possess either unsurpassed technical skills or is able to command the market.

Overseas exposure is regarded by many interviewees as a requisite for partnership because it allows a partner to be adaptive to changing client needs and be able to build more extensive client relationships. Cultural exposure is something vital in global multi-national corporations like the Big 4 firms. 


\section{MInstitute Macrothink}

International Journal of Accounting and Financial Reporting

ISSN 2162-3082

2018, Vol. 8, No. 2

"You still need to go overseas for engagements. We still have the exposure, we still see different things, depending on really the engagement. And nowadays all the engagement is really multinational, where it is not just Singapore." - Interviewee

"International exposure in this globally connected world is paramount especially in a small country like Singapore, where you do not have a big hinterland, so everybody you work with is all generally international businesses. So, that is quite important." Interviewee

With automation on the rise in most industries, it is also important for partners to be IT savvy and be aware of the potential IT related risks.

"With the conception of data analytics in audit, it provides extra insight to our clients and replaces some of our audit testing. It would certainly add value to a candidate's portfolio as it allows for audit in a more efficient way because of the fee pressure and the rising salary" - Interviewee.

In addition to the above positive traits that would spur partnership, it would be worthwhile to be aware of characteristics and behaviors that deter partnership. The first pitfall to partnership is the lack of persistence. Some individuals do not make partners because of their inability in getting along with the people they work with.

The focus of the discussion above is on Big 4 Partners in general. Given that the Big 4 firms have several service lines, it is important to explore whether there are differences in skill sets required of Partners across various service lines?

Most interviewees believe different skill sets are required across service lines, with the distinguishing factor being whether the service line is more focused on portfolio management, e.g., Audit, which would call for characteristics such as team management and technical competency, or on client scouting, e.g., advisory, which calls for effective client communication and the ability to build client networks.

\section{Discussion}

Our results highlight an important point - nurturing partner attributes may involve a development process. In the Big 4 accounting firms, it is the responsibility of the partners to identify and nurture high-potential, leadership talents who are 'on-track' to become future partners (Carter \& Spence, 2014). These accounting firms invest resources to provide these emerging leadership talents with rich developmental experiences. For example in at least two of the Big 4 accounting firms, the interviewees mentioned their firms assigned senior partners as mentors of the high potential individuals with the aim of offering advice on career development and progression. In addition, interviewees also highlighted the critical role played by management leadership programmes in partner development process. Such programmes can enhance the effects of direct leadership behaviours. For example, interviewees shared with us that encouraging innovative thinking is more likely to increase innovation when the firm puts in place a programme that facilitates innovation, a climate of 
psychological safety for risk taking and appropriate rewards for creative ideas about improving services and processes.

A few interviewees also highlighted the importance of having role models in the partner development process (Kornberger et al., 2011). This coincides well with the proposition of social learning theory. According to social learning theory, the way in which humans learn new behavior is through imitation of role models. In situations of ambiguity, role models can set norms for appropriate behavior, thus triggering behavioral imitation. This is common in the Big 4 settings. For example in team interaction settings such as team meetings, which are often held for problem-solving purposes, such ambiguity could put leaders in a position of leading by (behavioral) example. Thus when leaders communicate about ideas and solutions, team members may explicitly or implicitly perceive this as appropriate behavior, and follow accordingly with their own ideas and solutions to problems. Partners could foster solution communication in followers which suggest that leading by example can meaningfully impact subordinates' attitudes and behaviors in the workplace.

Besides acting as role models, partners also play the role of transformational leaders (Morris \& Pinnington, 1998). Our results show that partners can trigger idea generation and solutions by team members, which corresponds to the notion of sense-making through leadership in team setting. Sense-making is "about such things as the placement of items into frameworks, comprehending, redressing surprise, constructing meaning, interacting in the pursuit of mutual understanding and patterning. In fact, Zaccaro and colleagues (2001) discuss sense-making as the critical point in understanding how leaders can influence a team. During team interaction process, transformational leaders in particular can facilitate sense-making for team members by helping them interpret events and available data, developing a shared mental representation of a problem, helping team members generate solutions to identified problems, developing strategies and creating commitment toward implementing those solutions, and by conveying a vision for improving the team's collaboration and performance outcomes.

The other mechanism in the partner development process is the extent to which common exposure among the managers takes place can affect the emergence and evolution of leadership. For example in our research, interviewees shared with us it is common practice for partners of the Big 4 Accounting firms to bring along managers and senior managers, particularly the high potential ones, to client meetings. Besides helping managers to broaden their client network, it is also an opportunity for these managers to witness how partners handle clients effectively. In such setting, managers can learn to better communicate and connect with clients and in turn, strengthen their client management skills.

While it is important for the Big 4 accounting firms to actively provide emerging leadership talents with rich developmental experiences, it is ultimately the individual's responsibility for taking ownership in his or her own development. These high potential individuals need to be ready, go through and reflect on their experiences that ultimately shape their attribute development process. 


\section{Conclusion}

In this study, we interviewed 24 partners and 'partners-to-be' from the Big 4 Accounting firms in Singapore and identified a number of attributes of a partner. Essential attributes include technical expertise, strong client relationship, solid leadership skill, team management skill, a strong sense of integrity and ethics, and good business sense. There are a few 'good to have' attributes that include overseas exposure, being IT savvy and having ' $X$ ' factor. In light of current digital revolution, future research may want to study the level of IT awareness and proficiency a partner ought to possess in the future digital economy. Perhaps being IT savvy may need to be upgraded from 'good to have' to become an essential attribute of a partner. Our study also highlighted nurturing partner attributes may involve a development process. Mechanisms within the partner development process include having senior partners to be mentor, imitate a role model, sense-making through leadership and wide exposure to clients. Future study may assess how critical are these mechanisms in the development process in nurturing attributes of a partner. The implication is that if proven critical, the Big 4 accounting firms may consider formalizing these mechanisms in the development process of making partner.

The results of the study are testament to the growing importance of entrepreneurial aptitude in one who aspires to be a Big 4 accounting partner in Singapore context. Nonetheless, technical competence remains an integral aspect of a partner's portfolio, among other equally important attributes such as communication skills and business savvy. Moving forward, it would be important for hopeful Big 4 associates to acquire IT related skills in order to deal with disruptive changes brought by technology, where higher level analytics may potentially displace those who remain traditional and fail to adapt to higher order thinking in their work.

Overall, our study made a few major contributions. First, the study contributes with a rich ethnographic analysis of the attributes of partners in the Big 4 accounting firms in Singapore. This extends prior studies (e.g., Carter and Spence, 2014) which are predominantly conducted in Western contexts such as Canada, France and UK, to an Asian setting such as Singapore. This study also contributes to practice. Human capital development is a major investment for Big 4 accounting firms. Our findings should provide insights to key attributes that are required for career progression within the Big 4 accounting firms. Accounting practitioners will be keen to understand what kind of employees they should hire and what kind of training they should provide. This study also benefits accountancy degree programmes in Asia. Many accounting university students join the Big 4 accounting firms upon graduation and aspire to be a partner. Gaining an insight into the qualities of a partner should also be useful to accounting academics as it offers valuable insights that shape accounting pedagogy and curriculum. As accounting programmes groom their students to be future leaders of the Big 4 accounting firms, it is important to understand what skillsets their students should embrace during their time with the programme.

While it is many accounting graduates' dream to make partner at a Big 4 accounting firm, it is important to note that being a partner, entails more responsibility. A partner has to handle client relationships, ensure that new business is coming into the firm, and keep expenses in 


\section{Macrothink}

International Journal of Accounting and Financial Reporting

ISSN 2162-3082

line. Partners meet periodically to make decisions regarding hiring/firing/compensation decisions, as well as the overall direction of the firm. In addition, partners also have to supervise the work of others. Therefore, it is important to learn what being a partner really means, rather than just focusing on the perceived status and financial rewards.

\section{References}

Anderson-Gough, F., Grey, C., \& Robson, K. (2000). In the name of the client: The service ethic in two professional services firms. Human Relations, 53(9), 1151-1174.

Anderson-Gough, F., Grey, C., \& Robson, K. (2001). Tests of time: organizational time-reckoning and the making of accountants in two multi-national accounting firms. Accounting, Organizations and Society, 26, 99-122.

Barrett, M., Cooper, D. J., \& Jamal, K. (2005). Globalization and the coordinating of work in multinational audits. Accounting, Organizations and Society, 30, 1-24.

Carter, C., \& Spence, C. (2014). Being a successful professional: An exploration of who makes partner in the Big 4. Contemporary Accounting Research, 31(4), 949-981.

Cooper, D. J., \& Robson, K. (2006). Accounting, professions and regulation: Locating the sites of professionalization. Accounting, Organizations and Society, 31, 415-444.

Covaleski, M. A., Dirsmith, M. W., Heian, J. B., \& Samuel, S. (1998). The calculated and the disavowed: Techniques of discipline and struggles over identity in Big Six public accounting firms. Administrative Science Quarterly, 43, 293-327.

Gendron, Y., \& Spira, L. (2010). Identity narratives under threat: A study of former members of Arthur Andersen. Accounting, Organizations and Society, 35(3), 275-300.

Gibbins, M., McCracken, S., \& Salterio, S. E. (2010). The auditor's strategy selection for negotiation with management: Flexibility of initial accounting position and nature of the relationship. Accounting, Organizations and Society, 35, 579-595.

Greenwood, R., \& Suddaby, R. (2006). Institutional Entrepreneurship in Mature Fields: the Big Five Accounting Firms. Academy of Management Journal, 49(1), 27-48.

Grey, C. (1998). On being a professional in a "Big Six" firm. Accounting, Organizations and Society, 23(5-6), 569-587.

Kornberger, M., Justesen, L., \& Mouritsen, J. (2011). "When you make manager, we put a big mountain in front of you": An ethnography of managers in a Big 4 Accounting firm. Accounting, Organizations and Society, 36(8), 514-533.

Malsch, B., \& Gendron, Y. (2013). Re-theorizing change: Institutional experimentation and the struggle for domination in the field of public accounting. Journal of Management Studies, $50(5), 870-899$. 


\section{MInstitute ${ }^{\text {Mink }}$}

International Journal of Accounting and Financial Reporting ISSN 2162-3082

McCracken, S., Salterio, S. E., \& Gibbins, M. (2008). Auditor-client management relationships and roles in negotiating financial reporting. Accounting, Organizations and Society, 33(4-5), 362-383.

Robson, K., Humphrey, C., Khalifa, R., \& Jones, J. (2007). Transforming audit technologies: Business risk audit methodologies and the audit field. Accounting, Organizations and Society, 32(4-5), 409-438.

Sikka, P. (2008). Enterprise culture and accountancy firms: new masters of the universe. Accounting, Auditing and Accountability Journal, 21(2), 268-295.

Sikka, P. (2009). Financial crisis and the silence of the auditors. Accounting, Organizations and Society, 34, 868-873.

Spence, C., \& Carter, C. (2014). An exploration of the professional habitus in the Big 4 accounting firms. Work, Employment and Society, 28(6), 946-962.

Suddaby, R., Cooper, D. J., \& Greenwood, R. (2007). Transnational regulation of professional services: Governance dynamics of field level organizational change. Accounting, Organizations and Society, 32, 333-362.

Suddaby, R., Gendron, Y., \& Lam, H. (2009). The organizational context of professionalism in accounting. Accounting, Organizations and Society, 34, 409-427.

\section{Appendix A}

Sample questions for the interview

- What are the key criteria in being recruited into the Big 4 ?

- What is the relative importance of the following attributes during recruitment: education background, technical ability, soft skills, English proficiency, and existing social/professional networks?

- Can you describe the process through which you were initially recruited?

- Can you give a brief overview of your career up until this point?

- How did you get appointed to your current role/position within the firm?

- In your view, what are the key skills and attributes that are needed for career progression within your firm?

- Do people at different levels in the organization (e.g., partners versus directors versus managers) have different skill sets?

- Do people in different service lines (e.g., audit versus consulting) have different skill sets? 
- What are your career ambitions and do you think they are achievable?

- Do you think that career progression is based primarily on individual abilities or other criteria?

- How important are social networks, both internal and external, to career progression?

Note

Note 1. The Big 4 accounting firms relate to the four biggest international accounting firms. They are Deloitte, Ernst and Young, KPMG and PricewaterhouseCoopers.

\section{Copyright Disclaimer}

Copyright for this article is retained by the author(s), with first publication rights granted to the journal.

This is an open-access article distributed under the terms and conditions of the Creative Commons Attribution license (http://creativecommons.org/licenses/by/4.0/) 